\title{
9 The Legacy of the New Order Military in Local Politics: West, Central and East Java
}

\author{
JUN HONNA
}

Post-Soeharto scholarship regarding the Indonesian military (Tentara Nasional Indonesia, TNI) has largely concentrated on two areas of military politics: first, institutional reform at the national level, such as the elimination of the sociopolitical section in the military organisation and military neutrality in national elections; and second, the military involvement in political violence in remote areas. ${ }^{1}$ Such studies leave an important question untouched: civil-military relations in the everyday politics of 'non-conflict' areas where most citizens live. How have democratisation and decentralisation re-shaped local elite politics and civil-military relations? What legacies of the New Order military remain consequential for political dynamics at the local level? This chapter tries to answer these questions by focusing on political developments in West, Central, and East Java. ${ }^{2}$

The focus of this chapter is on the period between the two general elections in 1999 and 2004. This was the first phase of Indonesia's democratic transition, and the one in which New Order legacies were most clearly defined. We first look at the re-shaping of local power elites in the three provinces immediately after the 1999 general elections, then the changes brought about by decentralisation policies from 2001 and the attendant rise of new political strategies for diverting funds from development projects and maintaining political power. Finally, we focus on the gubernatorial elections in 2003 as a case study to elucidate the theatre of civil-military politics and its contribution to the fortification of local civil-military elite collusion.

\footnotetext{
1 For scholarship on military reform, see, for example, Honna, 2003, Chapter 7, and Mietzner, 2006. Military violence in remote areas is well analysed in Sukma, 2004, and Davies' unpublished paper.

2 I thank Edward Aspinall for his invaluable comments on the manuscript. For a more extensive version of the argument used in this chapter, see Honna 2006
} 
Although the power of the military to dominate and direct local political and economic affairs has clearly declined since the end of the New Order, the analysis presented in this chapter suggests that the TNI remains an important player in even the relatively economically advanced regions. Local military actors have adroitly adapted to the new institutional framework, taking advantage of political competition between civilian elites and the rise of new privatised forms of violence to both promote themselves as neutral arbiters in local political contests and to secure access to political resources. In acting in this way, however, local military elites are not serving ideological ideals or obeying commands from the centre. Instead, local TNI officers have a high degree of autonomy and they are very flexible. They take action in order to maintain and defend the military's distinctive political, economic and other corporate interests. In this sense, they have become merely one among many players in post-Soeharto local politics, albeit one which the new civilian political elites are almost invariably eager to accommodate.

\section{The 1999 elections and the re-shaping of local elites}

Local politics during the Soeharto era were controlled by the trinity of Golkar, the military and bureaucracy. ${ }^{3}$ Jakarta's central government distributed development budgets to local governments which then allocated these funds to various projects. Local business groups were instructed to affiliate with Golkar if they wanted to participate in these projects. This traditional 'concession regime', consisting of Golkar, local bureaucrats and business elites, became deeply embedded in the local political economy during the three decades of Soeharto's rule. The military played a watchdog role, using coercion to repress social forces which threatened the concession regime. During elections, Golkar's dominance was secured by the military, bureaucrats and business elites.

This structure of local dominance faced a serious challenge in the 1999 general elections, following the wave of support for democratisation and reformasi that had precipitated the fall of Soeharto in 1998. The elections resulted in the victory of Megawati Soekarnoputri's Indonesia Demokrasi Party of Struggle (Partai Demokrasi Indonesia-Perjuangan, PDI-P) which obtained 34 per cent of total votes at the national level, and defeated Golkar (22 per cent) - its first electoral defeat since the beginning of the New Order. The 1999 elections also brought about the collapse of Golkar dominance in local parliaments, where PDI-P now emerged as the leading party in 13 provincial parliaments. In the provinces which are the focus of this chapter, PDI-P came first in Central Java

3 On the role of the military in the New Order polity, see Crouch 1978. 
44 per cent) and West Java (33 per cent) and ran a close second (34 per cent) to the National Awakening Party (Partai Kebangkitan Bangsa, PKB) (35 per cent), in East Java. PDI-P also won majorities in 76 out of 99 parliaments (about 80 per cent) at the regency level in the three provinces. This sweeping electoral victory of the PDI-P effectively ended the dominance of Golkar and forced modification of established concession regimes at the local level. The power shift in local parliaments compelled local governments to form new alliances with new political elites in distributing the benefits of concession businesses and development projects. It also encouraged businesspeople to work closely with PDI-P politicians, many of whom were also local entrepreneurs. In this way, the centre of the local politico-economic power shifted away from Golkar to the PDI-P.

The 1999 elections also influenced the position of the military in local politics in these provinces. The military's regional commands which had uniformly supported Golkar during the New Order era had to adapt to the new environment. In places where Golkar retained parliamentary supremacy, the military maintained existing ties, while where the PDI-P won the elections, regional military commands had to forge new alliances in support of the new local concession regime. This dynamic led to the collapse of the military's uniform nation-wide political orientation and forced military commands to respond to local political developments. Unlike in the past, local commands now had greater institutional flexibility and discretion in adjusting to everyday local politics. This trend was reinforced by the financial problems being experienced by military commands, precipitated by the bankruptcy of many military businesses following the 1998 Asian economic crisis. In consequence, many commands that had relied on 'subsidies' generated by these military businesses were forced to develop their self-financing capacities. In the new era, this meant deepening ties with local elites who had access to economic resources.

For instance, the Siliwangi Military Division (Kodam III/Siliwangi), which oversees West Java, is widely known to have business partners, including local timber traders who are deeply involved in illegal logging in West Java. In forests near the Citarun River in Bandung and the Cimanuk River in Garut, for example, illegal logging is conducted by local gangs and dealers who depend on the security apparatus to transport logs. ${ }^{4}$ It also appears that a human trafficking

4 Interviews with a local journalist from Pikiran Rakyat (Bandung), 21 June 2004 and a member of the local environmental NGO, DPKLTS (Dewan Pemerhati Kehutanan dan Linkungan Tanah Sunda), 22 June 2004. Stories about this kind of illicit trade do not appear in local media because of pressures brought to bear on editors. 
syndicate in Indramayu, the illicit drug trade in Bandung, and a youth gang specialising in vehicle theft in Bandung are generating opportunities for protection rackets operated by local military commands. ${ }^{5}$

In Central Java since 1998, the Diponegoro Command (Kodam IV/Diponegoro) has been facing agitation by local civil society groups demanding the return of land seized by the military in the wake of the military-orchestrated killings and persecution of alleged communists in the mid-1960s. These mobilisations have been organised mostly by the families of former communists, whose land was confiscated, along with a younger generation of liberal-minded and leftist activists affliated with Nahdlatul Ulama (NU), the largest Muslim organisation in Indonesia, who have been pioneering a process of reconciliation with vicitims of the 1960s killings and repression. To protect land that has been used by the Kodam Diponegoro for its business activities, the local military elite has sought political protection, leading to a new alliance with PDI-P politicians (interview, 13 January 2004). At the same time, Kodam ratcheted up its propaganda campaign 'bahaya ex-tapol' (danger of ex-political prisoners) and relied on its intelligence services to approach kiai (Islamic teachers) and persuade them to not join the land campaigns led by young NU leftists.

In East Java, the Brawijaya Military Division (Kodam V/Brawijaya) and the Eastern Naval Fleet Command long profited from real estate and protection rackets involving industrial areas and red-light districts in Surabaya. ${ }^{6}$ These activities depended on the co-operation of the local government and parliament which, after the defeat of Golkar, required the military to switch its attention to the new dominant political forces in East Java, namely the PKB and the PDI-P.

\section{Decentralisation and new patterns of elite bargaining}

The next wave of change in the pattern of concession hunting among local elites resulted from the introduction of another reform, decentralisation. Decentralisation legislation, passed in 1999 and implemented in 2001, transferred

\footnotetext{
5 West Java political actors generally believe that these operations are conducted or at least managed by local preman (hoodlums) affiliated with powerful ethnic associations, namely Angkatan Muda Siliwangi (AMS) and Gabungan Inisiatif Barisan Siliwangi (GIBAS). However, the organised vehicle theft, is monopolised by a group of high school drop-outs who call themselves Briges (Brigadir SMA 7) after their high school.

6 It is well-known that the sex industry in Surabaya, perhaps the largest in Indonesia, operates under army and navy protection. Large entertainment and amusement places are said to be protected by the navy, while short-stay hotels and street prostitution is controlled by the army. This 'gentlemen's agreement' in favour of the navy is accepted by the army because it overwhelmingly controls the real estate business in East Java. Interviews with two local journalists (24 June 2003) and the director of a gender-issue NGO (25 June 2003) in Surabaya.
} 
management of local economic resources from the central government to local governments, especially at the regency/city level. As a result, competition over these resources intensified among local elites. In the three provinces of West, Central and East Java, escalation of intra-elite contestation typically centred on regional governments' development projects. Local bureaucrats spoke of 'good governance' and 'administrative transparency' in project implementation, but in many cases tenders and bids were orchestrated and manipulated behind the scenes, allowing for the diversion of state funds to bureaucrats, politicians and their allies.

A new government ordinance in 2000 required local leaders (governors, district heads (bupati), and mayors) to submit annual 'accountability reports' (laporan pertanggunjawaban) to examination by local parliaments. If local councillors voted to approve the reports, local leaders would remain in office; if they withheld approval, the leaders would lose office before completing their term. This new rule meant governors, bupati and mayors greatly intensified their efforts to woo and co-opt majorities in their local assemblies and resulted in a redistribution of largesse away from central authorities to local rent seekers. Local government heads typically approached members of the leading faction in the local parliament, and took 'necessary measures' to successfully shepherd their accountability reports through the approval process. Such measures typically involved allocating contracts for government projects to companies linked with faction leaders and extracting slush funds from the routine budget as 'operational funds' for faction members. If the region was rich in economic resources, the proportion of locally acquired revenue (Pendapatan Alokasi Daerah, or PAD) in the government budget was high as was the level of corruption, including bribery of local councillors.

For example, in Bandung city, the government allocated eight per cent of PAD for the city council in fiscal year 2002. This was almost twice the level in the Soeharto era and part of a 400 per cent increase in total government expenditure for the city council since 1997. ${ }^{7}$ According to civil society organisations, increases in the local council budget were principally aimed at co-opting it (interviews 29 March 2004; 30 March 2004). Meanwhile, members of Bandung's political community believe that about half the value of any government contract is transferred to whomever mediates between the contractor and government (typically, the mediator is a politician or bureaucrat) as a kickback. Local NGOs tried to monitor murky aspects of city budgets, including expenditures for the city council, with limited success. As one local NGO leader explained

7 For the budgetary problems in Bandung, see Haryadi and Sumindar, 2002. 
It is extremely difficult to conduct research on how the budget is actually used, because it involves the problem of tenders in public projects and procurements. Once we touch on these issues, we are confronted by endless intimidation (interview 30 March 2004).

Central Java is a stronghold of PDI-P; the towns of Semarang, Solo, Kudus, and Cilacap are known as PAD-rich districts where local governments manage 'operational funds' in abundance. Moreover, in Central Java, 20 out of 35 local government heads (bupatis and mayors) between 1999 and 2004 were PDI-Paffiliated, meaning that in these places the party dominated both executive and legislative branches. Indeed, in the regencies of Semarang, Grobogan, Tegal, Pemalang, Banyumas, Kebumen, Magelang, Kendal, Batang, and Kudus, bupatis were simultaneously the heads of local PDI-P branches. In such places, PDI-P leaders before long began behaving like local kings (raja lokal), who reigned the concession regime. The PDI-P itself became the site of the most vigorous lobbying regarding local development projects.

These new dynamics in legislative and executive politics influenced civil-military interactions at the local level. Many heads of local governments now enjoy wider discretion in allocating economic resources, having at their disposal large amounts of 'tactical funds' which were used to maintain or buy support from salient bureaucratic networks, including local military institutions. As Mietzner argues, the executive branches of local government found it advantageous to cultivate good relations with TNI, given the fractious and fickle nature of local legislatures (Mietzner 2003:254). Politically savvy regents and governors knew it was important to co-opt the TNI, as it held a block of parliamentary seats which could cast the deciding vote during approvals of accountability reports (until 2004, the TNI and police were allocated ten per cent of seats in local legislatures). Unlike many civilian councillors who were susceptible to lobbying from pressure groups, councillors in uniform tended to follow instructions from local military headquarters. Therefore, local government leaders often found it relatively straightforward to secure votes in a local parliament by lobbying the territorial command. TNI elites in local commands in turn understood the value of the swing vote, and offered support in return for policy rewards.

For example, the reward could be budgetary allocation for projects - such as land development and transportation business - linked to local military enterprises. The other important reward could be the extension of TNI's access to the administrative decision-making process. Here, the role of the Regional Leadership Assembly (Musyawarah Pimpinan Daerah, Muspida) should be highlighted. Muspida was a New Order-era institution which combined local leaders of executive government and key local security officials, aiming to discuss regional political issues under the leadership of governors, bupatis and 
mayors. ${ }^{8}$ Interestingly, Muspida has not only survived into the post-reform era as one of the few channels through which the military can exercise a direct influence on local political affairs, but it is also expanded in some regions by including more military officers - such as commanders of Military Sub-District Commands (Komando Rayon Militer, Koramil) and strategic battalions - in the assembly. As one bupati explained

the military is crucial for political stability here, and I have successfully incorporated TNI in my administration by giving it more say in Muspida, which is now called Muspida $++{ }^{9}$

The term Muspida++ refers to the expanded version of the assembly, and it is this political initiative of bupati that has helped them co-opt TNI into the administration, which in turn has increased TNI's direct influence on the everyday local governance after the New Order. ${ }^{10}$

In sum, between 1999 and 2004, local military elites effectively exploited the political vulnerabilities of local leaders who now enjoyed wider discretion in using economic resources. The new framework provided ample opportunity for the military to draw on its intelligence, political and security strengths to take advantage of decentralisation, forge new alliances and develop new methods for resource extraction.

\section{Military politics in gubernatorial elections}

The advantages conferred on the TNI by this situation were evident during elections of top local executive positions. The 2003 gubernatorial elections in West, Central and East Java were excellent examples of how local military commands adopted virtual king-making roles in this new context. ${ }^{11}$

In West Java, the gubernatorial election was conducted in May. The balance of party politics favoured the PDI-P, which formed the largest faction in

\footnotetext{
8 Muspida was formulated by Soeharto's presidential decree in 1986. At the regency level, the New Order Muspida was typically constituted by bupati, the commander of Kodim (Military District Command), the head of resort police, the chief of district public prosecutor, the head of district court, and the speaker of the local parliament.

9 Interview with Samsul H. Siswoyo, bupati of Jember, East Java, 26 June 2003. In the case of Jember, Muspida during the New Order invited only the Kodim Commander from the military, but after the 1999 elections and under the leadership of post-New Order bupati, not only Kodim Commander but also battalion commanders were invited to provide policy input to Muspida.

10 In Central Java, the similar Muspida expansion can be found in Semarang where the mayor has incorporated many TNI officers in what he calls 'Muspida+'. Whether it is Muspida+ or Muspida++, there seems to be the same political aim, that is, giving local TNI a more say in the administration.

11 Until 2005, elections of local leaders were always carried out within local legislatures, rather than by direct elections by voters, a new system which began to be implemented in 2005 .
} 
the provincial parliament. From the outset, PDI-P's central and provincial executives wanted to nominate Rudi Harsatanaya, the head of PDI-P's West Java chapter and a long-time Megawati loyalist since the 1980s. This decision, however, provoked strong resistance from local elites who saw Rudi, a Chinese Sumatran, as not representing the Sundanese community. Sundanese power brokers blocked Rudi's nomination, and organised a statement of opposition to his nomination by seven PDI-P kabupaten branches. The anti-Rudi lobbying was led by two of the ethnic associations discussed, Angkatan Muda Siliwangi (AMS) and Gabungan Inisiatif Barisan Siliwangi (GIBAS), which called for 'a Sundanese governor for Sundanese society'. The prominent Sundanese leaders, Mashudi and G.P. Solihin, who were also both retired three-star generals, former commanders of Kodam Siliwangi, and former West Java governors, forcefully lobbied the local elite. Mashudi privately consulted with the Commander of Kodam Siliwangi, Major General Iwan Ridwan Sulandjana, himself a Sundanese (interview 29 March 2004; 22 June 2004).

In the face of such pressure, Megawati's party headquarters finally decided to withdraw the nomination of Rudi and joined a coalition with PKB which nominated as governor retired Major General Tayo Tarmadi, ex-commander of Kodam Siliwangi, in the expectation of securing the support of Siliwangi generals. However, it was predicted that the military would never support Tarmadi because he was unpopular, corrupt and would behave disrespectfully towards the current Siliwangi commander (interview 28 April 2003). These circumstances all benefited Golkar. The retired Major General Nurhaman, the head of Golkar's provincial branch had strong ties with local military elites in the Siliwangi Command. Backed by Mashudi and Solihin, Nurhaman worked effectively to convince TNI that it would be beneficial to support Danny Setiawan, the Golkar nominee for the governor's post (interview 22 June 2004).

The election was by a vote of all 100 members of the provincial legislature. Tarmadi expected to secure the 30 votes from PDI-P members and 12 from the PKB faction, totalling 42 votes. Golkar calculated that its own 21 votes and 27 from other parties would give it at least 48 votes. It was also believed that it could exploit the PDI-P's internal rift through vote buying (interview Heri Akhmadi 27 May 2003). The situation thus seemed to favour Setiawan. Satisfied with this turn of events, the TNI faction which had 10 votes in the provincial and district parliament (Dewan Perwakilan Rakyat Daerah, DPRD) decided to abstain from voting in the name of 'political neutrality'. By refraining from casting its votes, the TNI sent a clear message that it preferred Setiawan the civilian bureaucrat, to Tarmadi, the ex-military officer. Abstaining also helped to avoid an open breach with the PDI-P, still the dominant party in West Java. 
Thus, the Siliwangi Command adroitly assessed the political situation and secured its institutional interests without actually using its leverage or aligning itself openly with any of the rival civilian elites.

Two months later, in July 2003, another gubernatorial election was conducted in East Java. The incumbent Imam Utomo (also a former Kodam commander in East Java) was nominated by PDI-P for re-election and he was challenged by PKB which nominated Abdul Kahfi, a retired police brigadier general. The latter was 'recommended' by former president and PKB senior Abdurrahman Wahid, ignoring the preference of many NU leaders in East Java who wanted to form a coalition with PDI-P. The PKB held 33 seats in the 100-member DPRD against the PDI-P's 31. The third largest party, Golkar, had 11 seats and decided to support PKB. A coalition of small parties, also with 11 seats, supported PDI-P. Thus the power balance in the parliament was roughly equal, as one local politician put it, 'It was TNI which had the casting vote' (interview Achmad Ruba'ie 25 June 2003).

The fact that Utomo was a former Brawijaya Commander (1995-97) would not automatically guarantee support of the current commander, Major General A. D. Sikki. On the other hand, senior military officers in East Java found it hard to accept Abdul Kahfi because, in the TNI leadership in East Java, there was an institutional memory of 'bad times' during the Abdurrahman administration. The Brawijaya Command had been irritated by Abdurrahman who had relied on intelligence provided by kiai and repeatedly intervened in personnel matters involving Resort Military Command (Komando Resort Militer, Korem) commanders. Also in the last days of his presidency, Abdurrahman mobilised his militant supporters in East Java to fight against troops. The bad blood from this standoff explains the Kodam's hostility to Abdurrahman's nominee as governor, Abdul Kahfi, and their active lobbying against him.

Finally, the logic of preman politics also pushed TNI to defend Utomo. Powerful Madurese ethnic associations, such as Ikatan Keluarga Madura Indonesia (IKMI) and Ikatan Anak Buah Madura (IKABRA), were active behind the scenes in silencing NGOs which opposed Utomo's re-election. Ethnic preman circles were eager to block Kahfi's advance because they believed that he was close to a Jakarta gambling king who threatened to encroach on their turf. ${ }^{12}$ It was this underworld territorial war that encouraged IKMI and other preman groups, such as Forum Komunikasi Putra-Putri Purnawirawan ABRI (FKPPI) and Pemuda Panca Marga (PPM), to campaign for Utomo, including by intensively lobbying the Brawijaya Command itself.

12 According to a DPRD member who was a leader of Utomo's campaign team, Kahfi's main financer was Tommy Winata. Anonymous interview, 24 June 2003. 
Four days before election day, General Sikki gathered the local TNI top brass as well as FKPPI and PPM, and issued a political statement that Kahfi was not really a candidate of PKB, but rather of Abdurrahman Wahid. Those who attended this meeting at the Utami Hotel got the message that Kodam was behind Utomo. On 17 July 2003, Utomo was duly re-elected, gathering 17 votes on top of the expected 46, thanks largely to the support of TNI and the split within the PKB. As in West Java, local military elites assessed the civilian power balance, identified their institutional interests and acted accordingly. Here too they collaborated with local pressure groups to engage in political lobbying.

A week after the re-election of Imam Utomo, there was another gubernatorial election, this time in Central Java. This province was the second largest stronghold of PDI-P after Bali, and therefore it was expected that whoever won the party's support would win the election. Thus, Mardijo, the head of PDI-P's Central Java chapter and a long-time party loyalist, decided to mount a challenge to the re-election of incumbent Mardiyanto by nominating himself as the PDI-P candidate. However, Megawati's party headquarters told him to withdraw and instructed PDI-P to join forces with PKB in supporting Mardiyanto. Mardijo felt disgraced and decided to run for election anyway, a decision that led Megawati to dismiss him as provincial branch head. As a result, PDI-P, the largest party in Central Java, was split between those who supported Mardijo and those who obeyed Megawati's instruction to abandon him. Again, the contest among civilians effectively opened a space for politicking by the Kodam generals.

The split within the PDI-P was helpful to chief-of-staff of Kodam Diponegoro, Brigadier General Salim Mengga. At first, Mengga was torn between Mardijo and Mardiyanto, as the former represented the dominant concession elite (the PDI-P) in Central Java, while the latter had been his superior in 1997-98, when Mengga served as socio-political adviser under Mardiyanto as Diponegoro Commander. Megawati's decision to oppose Mardijo's ambitions solved Mengga's dilemma, giving him free rein to support Mardiyanto.

The role of NU in this election was also vital for Kodam. For five years, the Central Java NU had enjoyed good relations with Mardiyanto. Many kiai favoured Mardiyanto's re-election, which would facilitate further inflows from the development budget for their pesantrens. They opposed Mardijo, who had patronised the most militant segment of PDI-P's paramilitary wing, called Komunitas Marhaenisme (Komar). Komar's aggressive expansion in the underworld of Semarang and Solo had infringed on turf formerly controlled by NU vigilante corps (Banser). Frustrated Banser leaders lobbied kiai and NU executives to complain about this situation to Mardijo. NU thus favoured Mardiyanto in the gubernatorial election, and it was Muhammad Adnan, popularly called Gus Adnan, Chairman of the Central Java Branch of NU, who became the main broker involved in consolidating support for Mardiyanto. In 
order to cement its relationship with Mardiyanto, NU-via PKB - nominated the non-partisan Ali Mufiz, Deputy Chairman of NU's Central Java Branch, as his running mate.

Having secured this political arrangement, NU approached Kodam Diponegoro, promising that NU would maximise co-operation with TNI and the police to maintain social order after the elections. Mengga and his top brass welcomed this approach as they also were unhappy with Mardijo's Komar. Komar was thought to be involved with radical anti-TNI leftists who were demanding the return of lands seized by the New Order army in the 1960s, as discussed above. Quelling this movement was an institutional imperative for the Diponegoro Command, which stood to lose a great deal if it was forced to return the land in question. To avoid this scenario, it sought the support of NU for its campaign of 'vigilance' against ex-political prisoners. It was in this context that the local military elite joined forces with NU in supporting Mardiyanto's re-election. The voting in the DPRD was conducted on 24 July 2003. As anticipated, the PKB and TNI voted for Mardiyanto while PDI-P, although split between the two candidates, also favoured Mardiyanto propelling him to victory with 62 votes.

All three gubernatorial elections in Java demonstrate TNI's active political participation. There was no instruction from TNI headquarters in Jakarta to support either incumbents or candidates from the leading party, as was the case during the New Order. Rather, Kodams were given autonomy to support candidates who would maximise the interests of Kodam. In each case, TNI relied on its informal networks involving religious, ethnic and retired military elements. Generals proved adroit at manipulating civilian political competition and using their power to ensure their institutional interests were not compromised by electoral outcomes. In fact, these elections strengthened ties between local TNI and civilian elites.

\section{Politics of preman and the out-sourcing of violence}

As competition intensified among local political elites 'civic protest' became a covert means of lobbying for concessions and graft. Local legislators often used the strategy of mobilising 'local residents' to protest against projects in fields like land zoning and allocation, village or community development, and even welfare. The very politicians who orchestrated the demonstrations could then point to them as evidence of 'civil unrest' requiring establishment of special parliamentary committees (pansus) to discuss the problematic government project in question. Government officials in charge of the project had no choice but to 'consult' with the politicians who raised the issue. What typically 
happened was that these politicians then acted as 'mediators' in resolving the problem, making lucrative deals in the process. In exchange for 'calming' local residents, officials ensured that project contracts were allocated to companies connected to the 'mediator'.

This manipulation of protest to facilitate deals with government officials became a favoured and effective means of fundraising by local politicians, who exploited the need for post-Soeharto local governments to show they respected the concerns of citizens. Astute politicians organised various types of 'resident groups' prepared to pounce on any opportunity to shake down the government. Such groups came in the form of resident forums, youth groups, labour associations, farmer assemblies, environmental NGOs, ethnic delegations, religious representatives, to name a few. Political power increasingly came to be measured in terms of the scale of 'mass protests' that a politician could mobilise and the number of groups that he or she controlled. As one prominent politician claimed, 'access to local concessions now depends on how many corps (pasukan) you can prepare to demonstrate your importance to the government' (interview Ade Komaruddin 9 October 2003).

Manufacturing protests requires manpower. Since the economic crisis of 199798, which boosted the number of unemployed youth, recruitment of protestors has become easier, but it still requires mass brokers with the networks and muscle to get people onto the streets. Such brokers could be ethnic leaders, informal leaders of customary (adat) communities, religious teachers or, most importantly, local hoodlums (preman). Elite politicians with connections to the right brokers need only make a phone call to organise a mass protest. Indeed, many prominent local politicians work with several different brokers and thus enjoy the power to command the 'voice of the citizen' in very flexible ways.

During the New Order period, various preman groups, most infamously Pemuda Pancasila (PP) and PPM, enjoyed official sanction and in return performed coercive activities for the regime, such as strikebreaking. Since the end of the New Order, diversification of underworld power has been discernible, most notably with the growth of local ethnic groups, political party-affiliated youth organisations, and religious vigilantes. The proliferation of such organisations and their embrace of preman tactics has resonated with local power elites' increasing need of for mass mobilisation as a practical weapon in the everyday competition for concessions. In West, Central and East Java local politicians built alliances with preman in order to orchestrate 'popular' protests and hence tap into government economic resources.

In West Java, the capital city of Bandung and industrial areas of the northern coast have been hotbeds of preman. Here, a 'youth' organisation AMS, which was established by the West Java military command in the 1970s, is acknowledged 
as the most powerful preman group. AMS has regional branches in all West Java regencies and in the neighbouring province of Banten, and its structure resembles that of a military command, with its agents placed in many villages and districts for industrial workers.

This network, which links local elites and grassroots activists in a clientelistic way, has effectively countered many civil society organisations which attempt to promote mass solidarity based on the class interests of labourers and farmers. Several Bandung-based NGOs have endeavoured to organise both industrial workers along the north coast and agricultural employees in the southern area of the province (where many regencies, like Garut, Cianjur, Sukabumi, Ciamis and Tasikmalaya, remain relatively impoverished). These attempts, however, have been constantly blocked by the preman in the area who intimidate workers and villagers collaborating with NGOs from Bandung. Here, civil society movements trying to promote a class-oriented interest representation, based on 'horizontal' social solidarity, are countered by an elite model of organising the masses based on 'vertical' solidarity.

It is not only the AMS which has been significant in maintaining the elite's vertical model of mass mobilisation. A group which splintered from AMS in 2001, Gabungan Inisiatif Barisan Anak Sunda Siliwangi (GIBASS), also enjoys wide influence in Bandung. ${ }^{13}$ Members of GIBAS have helped the city administration resolve many 'problems' that could not be solved by legal means, such as eviction of street vendors and slum clearance for development projects. Both AMS and GIBAS claim to be safeguarding the ethnic interests of the Sundanese people, and their local networks are made available to prominent Sundanese political elites.

East Java is the heartland of NU power and influence. During the Abdurrahman Wahid presidency (1999-2001), East Java's underworld was largely taken over by NU's vigilante corps, Banser. The rise of the Abdurrahman presidency in 1999 encouraged Banser to expand its underworld activities, but his impeachment and replacement by Megawati in 2001 facilitated the emergence of a PDI-Paffiliated vigilante corps, Banteng Muda Indonesia (BMI), in the preman sector. BMI's aggressive expansion of protection rackets, ranging from traditional cockfights and secret lotteries (toto gelap or togel), to brothels and industrial extortion, ignited a public furore over its brutal methods. According to one local politician in East Java, BMI successfully took over major underworld territories previously controlled by Banser, except for places directly controlled by pesantren (interview Machmud Sardjujono 26 June 2003). BMI expanded its influence partly by allying with powerful Madurese ethnic associations, namely

13 GIBASS was later renamed as GIBAS by dropping 'Sunda' from the original name. GIBAS is said to be more 'militant' than AMS. 
IKABRA and IKMI. These groups found that BMI not only had few qualms about engaging in underworld business but also enjoyed direct access to the central government. The preman territory of East Java was, in this way, wrested from Banser by BMI, a process that relied on Madurese preman leaders whose reputation for aggressiveness and coarse behaviour was an obvious advantage in doing this sort of business.

Industrial areas in the Surabaya Bay, for example, have long been a playground of these ethnic preman groups. Since the end of the New Order, they have often been hired by enterprises to engage in strikebreaking and union busting and to evict poor residents to make way for development projects initiated by the city administration. They also have sent hit-men and kidnappers to terrorise NGO activists campaigning against evictions. As one local official put it,

It is stupid to kill NGO activists, because it is enough to make a phone call to them and then say 'I am now in front of your son's primary school'... You know this is not Jakarta where any tiny event like this may make news in the print media' (interview June 2003).

It is widely believed locally that top clients of IKABRA and IKMI include people from the inner circles of Imam Utomo, the Governor of East Java, Major General A. D. Sikki, the commander of Brawijaya Military Division, and some 'charismatic' Islamic teachers (kiai khos) linked to local politicians.

The growing political role of preman illustrates how decentralisation and democratisation initiatives have been captured by local elites in ways that have consolidated clientelistic practices in the post-Soeharto era. In particular, ethnic identities such as those of the Sundanese and Madurese have become very effective tools for political mobilisation, as they structurally bind local power elites and people in 'vertical solidarity' against the 'horizontal' model employed by the civil society movement. The ensuing atmosphere of intimidation and violence has largely muted the influence of local NGOs, media and other agencies which try to monitor the activities of the political elite and hold them accountable.

In this way, the utility of violence in political process is no longer dominated by local military commands, and political elites have increasingly relied on civilianised violence organised by preman groups. Importantly, TNI's withdrawal from direct political violence has effectively given the local military a relatively free hand in dealing with political competition among civilian elites. For civilian political elites, such a transformation of TNI is welcome, and these aspirants to political office almost inevitably seek support from the TNI, which is in turn in the position to weigh different offers and carefully calculate who are 
most suitable as strategic partners. Thus, it can be argued that, by out-sourcing violence to the preman proxy, TNI has effectively enhanced its bargaining power in the civilian local political competition.

\section{Conclusion}

This chapter has been concerned with the first phase of democratic transition in Indonesia, which lasted from the first post-Soeharto general elections in 1999 to the second in 2004. During this phase, the post-Soeharto reformasi movement promoted several significant democratic projects, including the 1999 elections themselves, decentralisation, civic participation in politics, and elections (not appointment) of local government heads. What was the political impact of these projects in Java and how did the TNI respond to the changing rules of the game and the shifting political landscape? Focusing on these questions enables us to clarify the legacy of New Order military in non-conflict areas.

Clearly, the democratising impact of the 1999 elections on elite politics was immense. They ended three decades of Golkar dominance. In about eighty per cent of all district and municipality DPRD in the three provinces new power elites affiliated with PDI-P became dominant, leading to the re-shaping of local concession regimes. In the face of this power shift, local military commands were given greater autonomy to adjust local alliances with civilian elites for the sake of securing their institutional interests.

Decentralisation also greatly modified the pattern of concession hunting among civilian elites. Access to increased resources and greater budgetary discretion led to more widespread corruption. Local legislators used their power to demand annual accountability reports from government heads to siphon off maximum benefits from development projects. The modus operandi of collusion has become pervasive and more sophisticated, outstripping the monitoring capacity of local anti-corruption NGOs. In order to share in the spoils of government, the territorial commands skilfully mobilised their bargaining power vis-à-vis local leaders. Revivified Muspida was one means by which civilian leaders used to buy political loyalty from the TNI.

In response to the growing role of civil society organisations, the political elite increasingly relied on preman brokers to mobilise mass support and to tap into concession projects. Patrimonial identities, such as those based on ethnicity, religion and kinship were used to counter class-based horizontal social solidarity. With some exceptions, this 'civilianisation' of violence reduced TNI's traditional role in containing civil society, helping the military to burnish its 
image and focus its institutional resources on securing its own interests. Thus, the out-sourcing of violence to preman bolstered TNI's credibility at the price of extensive gangster involvement in democratic processes and institutions.

These developments came together in the 2003 gubernatorial elections held in the three provinces in Java. It was expected that the election of governors would increase political accountability and improve local governance. Yet these elections considerably bolstered the political bargaining power of local military elites who skilfully exploited civilian competition for power and money, tactically collaborated with dominant social forces, and shrewdly developed ties with electoral victors.

It can be concluded that the legacy of the New Order was still very strong in local politics in West, Central and East Java during the first phase of democratic transition. This initial phase of political reformasi has now passed, but it continues to shape the direction of the second phase of political reform and democratic consolidation that began in 2005. Since 2005, local leaders have been popularly elected (see Mietzner in this volume), meaning also that the system of presenting annual accountability reports before local parliaments has ended. Also with the 2004 general elections, TNI's parliamentary seats were abolished. There are signs that these reforms are significantly altering the pattern of civilmilitary relations, with a further reduction of the military's influence on politics at the local level. At the same time, however, the legacy of the New Order system of pervasive military influence still lingers. The territorial structure of the military remains intact, military commanders still have access to local political decisionmaking through the Muspida structure, and the practice of self-financing of the local military budget continues at various command levels. The economic incentives created by self-financing continue to motivate local military officers to collude with business elites-including criminal entrepreneurs - who gain benefits from the political protection provided by local heads and parliamentarians. The institutional reforms enacted so far have not yet been sufficiently thorough to promote a truly robust civil society or to break local concession regimes. 